\title{
Synthesis and reactivity of rhodium(I) and iridium(I) complexes of the dianions of 2,3-pyrazinedicarboxylic and 2,5-pyrazinedicarboxylic acid
}

\author{
J.C. Bayón *, G. Net, J. Real, \\ Departament de Química, Universitat Autònoma de Barcelona, Bellaterra, 08I93 Barcelona, Spain \\ and P.G. Rasmussen * \\ Department of Chemistry, The University of Michigan, Ann Arbor, MI 48109 (U.S.A.)
}

(Received Octoher 2nd, 1989)

\begin{abstract}
Rhodium and iridium complexes of the title ligands have been prepared containing cyclooctadiene, carbonyl, phosphine and phosphite ancillary ligands. The complexes are mononuclear or dinuclear depending on the method of preparation and the leaving group basicity. The geometries of the complexes derived from the 2,3and 2,5-dianions show marked differences owing to differences in the steric interaction between the carboxyl groups. Clear structural assignments were made possible by the symmetry requirements revealed by the infrared and NMR spectra.
\end{abstract}

\section{Introduction}

The anions 2,3-pyrazinedicarboxylato $\left(\mathrm{cDcp}^{2-}\right)$ and 2,5-pyrazinedicarboxylato $\left(\mathrm{tDcp}^{2-}\right)$ have been extensively used as ligands for a wide range of transition metals. In addition to forming mononuclear complexes $\mathrm{M}(\mathrm{HcDcp})_{2}$, in which the ligand behaves as bidentate chelate [1], both dianions have been reported to give hydrated polymeric structures of composition (M(cDcp) $\cdot n \mathrm{H}_{2} \mathrm{O}$ [2] and $\mathrm{M}(\mathrm{tDcp}) \cdot n \mathrm{H}_{2} \mathrm{O}$ [3] $\left(\mathrm{M}=\right.$ divalent metal). The structures of the polymeric complexes $\mathrm{Co}(\mathrm{cDcp}) \cdot 2 \mathrm{H}_{2} \mathrm{O}$ and $\mathrm{Zn}(\mathrm{cDcp}) \cdot 3 \mathrm{H}_{2} \mathrm{O}$ show that different behaviour can be expected for the ligand when it is acting as a bridge. In the cobalt complex, the carboxylato groups are rotated by about $30^{\circ}$ each, in opposite directions with respect to the pyrazine ring, to avoid repulsive interaction between the endo-oxygens. In this way, the ligand can act as a double N-O chelate [4]. However, in the case of the zinc complex, only one of the sides of the ligand behaves as an $\mathrm{N}-\mathrm{O}$ chelate, while the other $\mathrm{N}$ atom remains uncoordinated. The carboxylato group next to it is rotated by $90^{\circ}$ with 
respect to the pyrazine ring, and the two oxygens of the group are coordinated to different metal atoms [5]. Polymeric structures containing the $\mathrm{VO}_{2}^{+}$cation [6], and $\mathrm{Ag}^{\mathrm{I}}-\mathrm{Ag}^{\mathrm{II}}$ mixed valence polymers [7] have been also prepared.

The only dinuclear species reported for these ligands are the ruthenium complexes of the $\mathrm{tDcp}^{2-}$ ligand [8] and two rhodium complexes of the $\mathrm{cDcp}^{2-}$ anion [9]. Recently, $\mathrm{tDcp}^{2-}$ and $\mathrm{cDcp}^{2-}$ have been used as ancillary ligands for preparing peroxo $\mathrm{Ti}^{\mathrm{IV}}$ complexes, and show striking differences in their coordination modes $[10]$.

We are engaged in the synthesis of a new type of dinuclear planar complexes which produce stacked structures in the solid state. We have found that the anions of imidazole-4,5-dicarboxylic acid [11] and pyrazole-3,5-dicarboxylic acid [12] are very effective ligands for forming such compounds. Some of the anionic iridium complexes can be chemically or electrochemically oxidized to form conducting materials [12]. An extension of our previous work is the use of $\mathrm{H}_{2} \mathrm{cDcp}$ and $\mathrm{H}_{2} \mathrm{tDcp}$ as dinucleating ligands for $d^{8}$ metal ions, which would allow the study of the influence of the overall charge of the complex in the formation of the stacks in the solid state.

\section{Experimental}

All reactions were performed under nitrogen by standard Schlenk techniques. Solvents were purified and dried by standard methods. $[\mathrm{M}(\mu-\mathrm{Cl})(\operatorname{cod})]_{2}[13],[\mathrm{M}(\mu-$ $\mathrm{OMe})(\operatorname{cod})]_{2}(\mathrm{M}=\mathrm{Rh}, \mathrm{Ir} ; \operatorname{cod}=1,5=$ cyclooctadiene $)[14]$ and pyrazine-2,5-dicarboxylic [15] acid were prepared as previously described. Other reagents were used as received.

\section{Physical measurements}

Elemental analyses were performed with a Perkin Elmer $240 \mathrm{C}$ instrument. Infrared spectra $\left(4000-400 \mathrm{~cm}^{-1}\right)$ were recorded on a Perkin Elmer Model 1710 Fourier transform spectrometer. Fourier transform ${ }^{1}$ H NMR spectra were recorded on a Bruker WP80SY or Bruker AM 400 instrument. Chemical shifts are reported in ppm downfield from tetramethylsilane.

Synthesis of $\left[R h_{2}(t D c p)(c o d)_{2}\right]$ (Ia). Method A: $4 \mathrm{ml}$ of an $0.1 M$ solution of $\mathrm{Me}_{4} \mathrm{NOH}$ in isopropanol/methanol $(0.4 \mathrm{mmol})$ were added dropwise to a suspension of $100 \mathrm{mg}$ of $[\mathrm{Rh}(\mu-\mathrm{Cl})(\operatorname{cod})]_{2}(0.2 \mathrm{mmol})$ and $34 \mathrm{mg}$ of $\mathrm{H}_{2} \mathrm{tDcp}(0.2 \mathrm{mmol})$ in $10 \mathrm{ml}$ of acetonitrile. A dark green solid separated. After $4 \mathrm{~h}$ stirring the product was filtered off and rinsed with acetonitrile and ether. Yield 99 ing (83\%). Method B: A suspension of $100 \mathrm{mg}$ of $[\mathrm{Rh}(\mu-\mathrm{OMe})(\mathrm{cod})]_{2}(0.2 \mathrm{mmol})$ and $34 \mathrm{mg}$ of $\mathrm{H}_{2} \mathrm{tDcp}$ $(0.2 \mathrm{mmol}$ ) was stirred for $4 \mathrm{~h}$ to give a precipitate of $100 \mathrm{mg}$ ( $83 \%$ yield) of the product, which was worked up as in method $\mathrm{A}$. The compound is soluble in $\mathrm{CH}_{2} \mathrm{Cl}_{2}$ and $\mathrm{CHCl}_{3}$.

Synthesis of $\left[\mathrm{Ir}_{2}(\mathrm{t} \mathrm{Dcp})(\mathrm{cod})_{2}\right](\mathrm{Ib})$. The procedure A used for Ia, but on a 0.15 mmol scale gave a $50 \%$ yield of a dark brown product. The yield was increased to $77 \%$ when method B was used. The complex is soluble in $\mathrm{CH}_{2} \mathrm{Cl}_{2}$ and $\mathrm{CHCl}_{3}$.

Synthesis of $\left(\mathrm{NMe}_{4}\right)[R h(c D c p)(\operatorname{cod})]$ (IIa). $4 \mathrm{ml}$ of an $0.1 \mathrm{M}$ solution of $\mathrm{Me}_{4} \mathrm{NOH}$ $(0.4 \mathrm{mmol})$ in methanol/isopropanol were added dropwise to a stirred suspension of $50 \mathrm{mg}$ of $[\mathrm{Rh}(\mu-\mathrm{Cl})(\mathrm{cod})]_{2}(0.1 \mathrm{mmol})$ and $34 \mathrm{mg}$ of $\mathrm{H}_{2} \mathrm{cDcp}(0.2 \mathrm{mmol})$ in $10 \mathrm{ml}$ of acetonitrile. The dark orange solution was evaporated to dryness. The residue was dissolved in a mixture of $8 \mathrm{ml}$ of acetonitrile and $2 \mathrm{ml}$ of methanol, and the solution 
was slowly evaporated under vacuum to give an orange precipitate. This was filtered off and rinsed with acetonitrile and ether to give $62 \mathrm{mg}$ of the product (68\% yield). This solid is hygroscopic and soluble in methanol.

Synthesis of $\left(\mathrm{NMe}_{4}\right)[\operatorname{Ir}(\mathrm{cDcp})(\mathrm{cod})](I I b)$. When $1.6 \mathrm{ml}$ of a $0.1 \mathrm{ml}$ of a solution of $\mathrm{Me}_{4} \mathrm{NOH}$ in methanol/isopropanol $(0.16 \mathrm{mmol})$ were added to a suspension of $50 \mathrm{mg}$ of $[\operatorname{Ir}(\mu-\mathrm{OMe})(\mathrm{cod})]_{2}(0.075 \mathrm{mmol})$ and $25 \mathrm{mg}$ of $\mathrm{H}_{2} \mathrm{cDcp}(0.15 \mathrm{mmol})$ in 10 $\mathrm{ml}$ of acetonitrile. A red solution was formed. The volume was reduced by one half and $15 \mathrm{ml}$ of ether were added to give a precipitate of $69 \mathrm{mg}$ ( $85 \%$ yield) of the orange product. The compound is very hygroscopic, and soluble in methanol and acetonitrile.

Synthesis of $\left[R h_{2}(c D c p)(\operatorname{cod})_{2}\right]$ (IIIa). Mixing of $100 \mathrm{mg}$ of $\left[\mathrm{Rh}(\mu \text {-OMe)(cod) }]_{2}\right.$ $(0.2 \mathrm{mmol})$ and $34 \mathrm{mg}$ of $\mathrm{H}_{2} \mathrm{cDcp}(0.2 \mathrm{mmol})$ in $10 \mathrm{ml}$ of acetonitrile immediately produced a precipitate of the brown product. After $4 \mathrm{~h}$ stirring to ensure completion of the reaction, the solid was filtered off and rinsed with methylene chloride; yield $101 \mathrm{mg}(83 \%)$. The product is only soluble in DMF and DMSO.

Synthesis of $\left[\operatorname{Ir}_{2}(c D c p)(\operatorname{cod})_{2}\right](I I I b)$. Treatment of $100 \mathrm{mg}$ of $[\operatorname{Ir}(\mu-\mathrm{OMe})(\operatorname{cod})]_{2}$ $(0.15 \mathrm{mmol})$ with $25 \mathrm{mg}$ of $\mathrm{H}_{2} \mathrm{cDcp}(0.15 \mathrm{mmol})$ in acetonitrile as described for the preparation of IIIa gave $70 \mathrm{mg}$ of the dark brown product $(60 \%)$. It is soluble in methylene chloride.

Synthesis of $\left[R h_{2}(t D c p)(C O)_{2}\left(P P h_{3}\right)_{2}\right](I V a)$. A red solution was formed when carbon monoxide was bubbled through a solution of $50 \mathrm{mg}$ of Ia $(0.085 \mathrm{mmol})$ and $45 \mathrm{mg}$ of $\mathrm{PPh}_{3}(0.17 \mathrm{mmol})$ in $5 \mathrm{ml}$ of methylene chloride. Layering of the solution with hexane produced $68 \mathrm{mg}$ of red crystals $(84 \%)$. The well-formed crystals lose solvent after a few seconds exposure to the atmosphere, even inside a capillary. The solid is very soluble in chlorinated solvents.

Synthesis of $\left[\operatorname{Ir}_{2}(t D c p)(C O)_{2}\left(P P h_{3}\right)_{2}\right](I V b) . \quad 30 \mathrm{mg} \mathrm{Ib}$ was treated as described for the rhodium complex IVa, to yield $32 \mathrm{mg}(72 \%)$ of a brown product. It is very soluble in chlorinated solvents.

Synthesis of $\left[R h_{2}(t D c p)(C O)_{2}\left(P(O R)_{3}\right)_{2}\right](R=P h, V a ; R=M e, V I a)$. The procedure described for the preparation of the complex IVa, but starting with $40 \mathrm{mg}$ of Ia gave $59 \mathrm{mg}(83 \%)$ of the red crystals in the case of $R=P h$, and $39 \mathrm{mg}(85 \%)$ of green crystals when $\mathrm{R}$ was Me. Both solids are very soluble in chlorinated solvents.

Synthesis of $\left.\left[R h_{2}(\mathrm{cDcp})(\mathrm{CO})_{2}(\mathrm{PPh})_{3}\right)_{2}\right](V I I a)$. Treatment of $20 \mathrm{mg}$ of IIIa as in the preparation of IVa gave $25 \mathrm{mg}$ of a brick-red complex (77\%).

Synthesis of $\left[R h_{2}(c D c p)(C O)_{2}\left(P(O R)_{3}\right)_{2}\right](R=P h, V I I I a ; R=M e, I X a) . \quad 30 \mathrm{mg}$ III a were treated similarly to give $26 \mathrm{mg}(49 \%)$ of the triphenylphosphite complex or $24 \mathrm{mg}(70 \%)$ of the trimethylphosphite complex. Both products are pale brown.

\section{Results and discussion}

A list of the compounds prepared and their analytical data is given in Table 1. Infrared and NMR data are shown in Tables 2 and 3, respectively. The compound VIIa has been previously reported [9].

The pyrazinedicarboxylic acids $\mathrm{H}_{2} \mathrm{cDcp}$ and $\mathrm{H}_{2} \mathrm{tDcp}$ differ remarkably in their reactions with the dinuclear species $[\mathrm{M}(\mu-\mathrm{Cl})(\operatorname{cod})]_{2}(\mathrm{M}=\mathrm{Rh}, \mathrm{Ir})$ in the presence of two molar equivalents of base. The ligand $\mathrm{H}_{2} \mathrm{tDcp}$ forms the expected dinuclear complexes $\mathrm{Ia}$ and $\mathrm{Ib}$, but $\mathrm{H}_{2} \mathrm{cDcp}$ yields the mononuclear compounds IIa and IIb, plus the complex anions $\left[\mathrm{MCl}_{2}(\mathrm{cod})\right]^{-}$. The infrared spectra of the species IIa and 
Table 1

Analytical data for compounds I-IX

\begin{tabular}{|c|c|c|c|}
\hline \multirow[t]{2}{*}{ Compound } & \multicolumn{3}{|c|}{ Analyses (found (calcd.)) (\%) } \\
\hline & $\overrightarrow{\mathrm{C}}$ & $\mathrm{N}$ & $\mathrm{H}$ \\
\hline$\left[\mathrm{Rh}_{2}(\mathrm{tDcp})(\operatorname{cod})_{2}\right](\mathrm{Ia})$ & $\begin{array}{l}44.9 \\
(44.9)\end{array}$ & $\begin{array}{c}4.88 \\
(4.76)\end{array}$ & $\begin{array}{c}4.43 \\
(4.45)\end{array}$ \\
\hline$\left[\mathrm{Ir}_{2}(\mathrm{tDcp})(\mathrm{cod})_{2}\right](\mathrm{Ib})$ & $\begin{array}{c}32.9 \\
(34.5)\end{array}$ & $\begin{array}{c}3.58 \\
(3.65)\end{array}$ & $\begin{array}{l}3.36 \\
(3.42)\end{array}$ \\
\hline$\left[\mathrm{NMe}_{4}\right][\mathrm{Rh}(\mathrm{cDcp})(\mathrm{cod})](\mathrm{IIa})$ & $\begin{array}{c}47.6 \\
(47.9)\end{array}$ & $\begin{array}{c}9.21 \\
(9.31)\end{array}$ & $\begin{array}{l}5.95 \\
(5.81)\end{array}$ \\
\hline$\left[\mathrm{NMe}_{4}\right][\mathrm{Ir}(\mathrm{cDcp})(\mathrm{cod})](\mathrm{IIb})$ & $\begin{array}{c}38.5 \\
(40.0)\end{array}$ & $\begin{array}{c}7.63 \\
(7.77)\end{array}$ & $\begin{array}{l}5.16 \\
(4.85)\end{array}$ \\
\hline$\left[\mathrm{Rh}_{2}(\mathrm{cDcp})(\mathrm{cod})_{2}\right](\mathrm{IIIa})$ & $\begin{array}{c}44.5 \\
(44.9)\end{array}$ & $\begin{array}{c}4.81 \\
(4.76)\end{array}$ & $\begin{array}{l}4.46 \\
(4.45)\end{array}$ \\
\hline$\left[1 r_{2}(\mathrm{cDcp})(\mathrm{cod})_{2}\right](\mathrm{IIIb})$ & $\begin{array}{c}33.3 \\
(34.5)\end{array}$ & $\begin{array}{c}3.86 \\
(3.65)\end{array}$ & $\begin{array}{l}3.38 \\
(3.42)\end{array}$ \\
\hline$\left[\mathrm{Rh}_{2}(\mathrm{tDcp})(\mathrm{CO})_{2}\left(\mathrm{PPh}_{3}\right)_{2}\right](\mathrm{IVa})$ & $\begin{array}{c}53.5 \\
(55.5)\end{array}$ & $\begin{array}{c}2.92 \\
(2.94)\end{array}$ & $\begin{array}{c}3.39 \\
(3.39)\end{array}$ \\
\hline$\left.\left[\mathrm{Ir}_{2}(\mathrm{tDcp})(\mathrm{CO})_{2} 9 \mathrm{PPh}_{3}\right)_{2}\right](\mathrm{IVb})$ & $\begin{array}{c}46.8 \\
(46.7)\end{array}$ & $\begin{array}{c}2.22 \\
(2.48)\end{array}$ & $\begin{array}{c}3.31 \\
(2.85)\end{array}$ \\
\hline$\left[\mathrm{Rh}_{2}(\mathrm{tDcp})(\mathrm{CO})_{2}\left(\mathrm{P}(\mathrm{OPh})_{3}\right)_{2}\right](\mathrm{Va})$ & $\begin{array}{c}50.4 \\
(50.4)\end{array}$ & $\begin{array}{l}2.68 \\
(2.67)\end{array}$ & $\begin{array}{c}3.06 \\
(3.08)\end{array}$ \\
\hline$\left[\mathrm{Rh}_{2}(\mathrm{tDcp})(\mathrm{CO})_{2}\left(\mathrm{P}(\mathrm{OMe})_{3}\right)_{2}\right](\mathrm{VIa})$ & $\begin{array}{c}24.5 \\
(24.9)\end{array}$ & $\begin{array}{c}4.04 \\
(4.14)\end{array}$ & $\begin{array}{l}2.94 \\
(2.98)\end{array}$ \\
\hline$\left[\mathrm{Rh}_{2}(\mathrm{cDcp})(\mathrm{CO})_{2}\left(\mathrm{PPh}_{3}\right)_{2}\right](\mathrm{Vlla})$ & $\begin{array}{c}53.6 \\
(55.5)\end{array}$ & $\begin{array}{c}2.94 \\
(2.94)\end{array}$ & $\begin{array}{l}3.53 \\
(3.39)\end{array}$ \\
\hline$\left[\mathrm{Rh}_{2}(\mathrm{cDcp})(\mathrm{CO})_{2}\left(\mathrm{P}(\mathrm{OPh})_{3}\right)_{2}\right]$ (VIIIa) & $\begin{array}{c}50.4 \\
(50.4)\end{array}$ & $\begin{array}{c}2.90 \\
(2.67)\end{array}$ & $\begin{array}{c}3.22 \\
(3.08)\end{array}$ \\
\hline$\left.\left[\mathrm{Rh}_{2}(\mathrm{cDcp})(\mathrm{CO})_{2}(\mathrm{POMe})_{3}\right)_{2}\right](\mathrm{IXa})$ & $\begin{array}{c}24.4 \\
(24.9)\end{array}$ & $\begin{array}{c}4.50 \\
(4.14)\end{array}$ & $\begin{array}{c}2.63 \\
(2.98)\end{array}$ \\
\hline
\end{tabular}

$\mathrm{IIb}$, in the $\mathrm{COO}^{-}$region, show bands at $1628 \mathrm{~cm}^{-1}(\mathrm{M}=\mathrm{Rh})$ and $1626 \mathrm{~cm}^{-1}$ $(\mathrm{M}=\mathrm{Ir}$ ) characteristic of free carboxylate groups, in addition to the bands of the in-plane coordinated carboxylate at $1672 \mathrm{~cm}^{-1}(\mathrm{M}=\mathrm{Rh})$ and $1680 \mathrm{~cm}^{-1}(\mathrm{M}=\mathrm{Ir})$.

Table 2

Infrared data $\left(\mathrm{cm}^{-1}\right.$ ) (in $\mathrm{CH}_{2} \mathrm{Cl}_{2}$ ) for compounds I-IX

\begin{tabular}{|c|c|c|}
\hline Compound & $\nu(O C O)_{a s}$ & $\nu(\mathrm{CO})$ \\
\hline Ia & 1663 & \\
\hline IIa & $1672 \quad 1628$ & \\
\hline IIIa & 16641686 & \\
\hline IVa & 1669 & 1988 \\
\hline VIIa & $1670 \quad 1694$ & 1984 \\
\hline $\mathrm{Va}$ & 1675 & 2014 \\
\hline VIIIa & $1677 \quad 1700$ & 2011 \\
\hline VIa & 1674 & 2005 \\
\hline IXa & $1673 \quad 1695$ & 2003 \\
\hline Ib & 1681 & \\
\hline IIb & 1680 & \\
\hline IIIb & $1684 \quad 1712$ & \\
\hline $\mathrm{IVb}$ & 1686 & 1969 \\
\hline
\end{tabular}


Table 3

${ }^{1}$ H NMR data (ppm) for compounds I-IX ${ }^{a}$

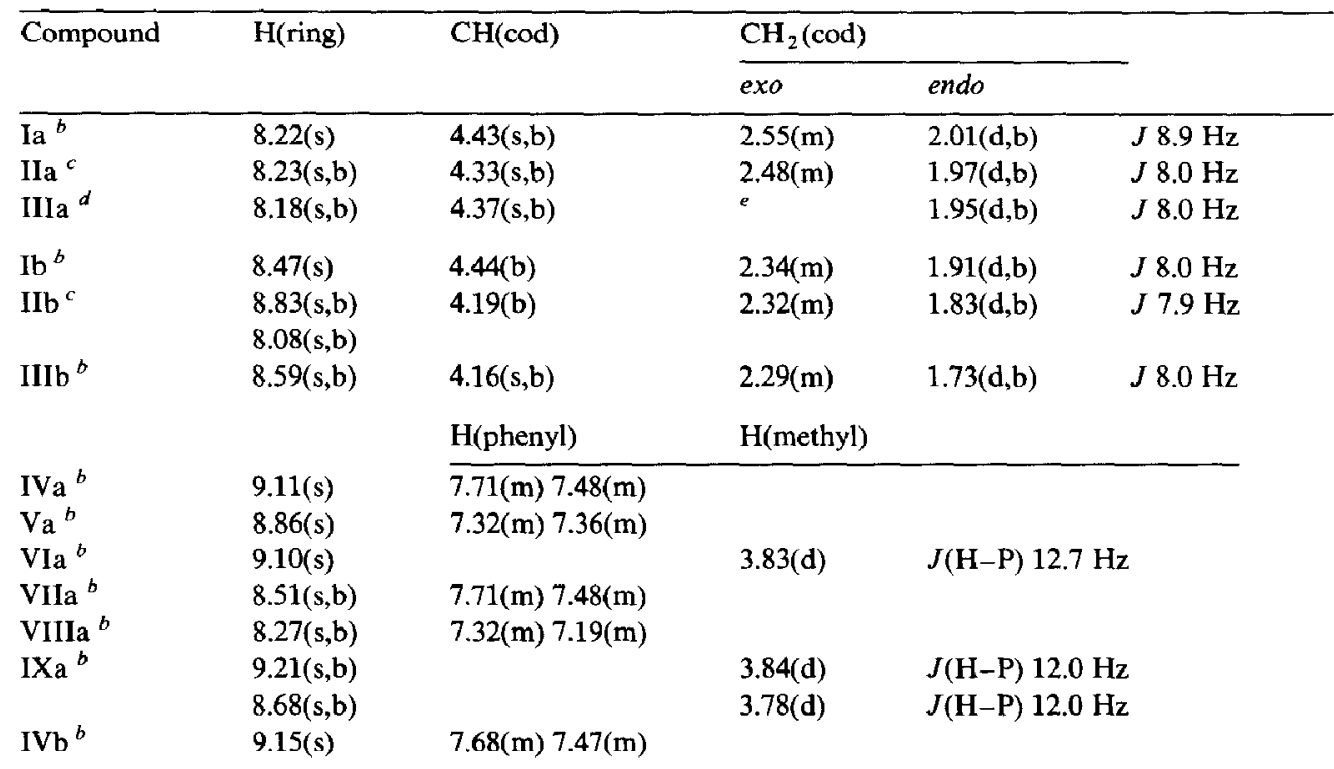

${ }^{a} \mathrm{~b}$, broad; d, doublet; $\mathrm{m}$, multiplet; s, singlet. ${ }^{b}$ in $\mathrm{CDCl}_{3} .{ }^{c}$ in $\mathrm{CD}_{3} \mathrm{OD} .{ }^{d}$ in DMSO. ${ }^{c}$ multiplet obscured by solvent signals.

These bands appear at nearly the same frequency of the single band observed for each of the dinuclear compounds Ia and $\mathrm{Ib}$, for which coplanarity of the pyrazine ring and a square-planar coordination environment of the metals is expected.

Dinuclear complexes derived from $\mathrm{H}_{2} \mathrm{cDcp}$ can be prepared by use of $[\mathrm{M}(\mu-$ $\mathrm{OMc})(\mathrm{cod})]_{2}(\mathrm{M}=\mathrm{Rh}$, Ir) as starting materials. The complexes IIIa $(\mathrm{M}=\mathrm{Rh})$ and IIIb $(\mathrm{M}=\mathrm{Ir})$, again show bands for in-plane coordinated carboxylato groups, together with a high frequency band at $1686 \mathrm{~cm}^{-1}(\mathrm{M}=\mathrm{Rh})$ or $1712 \mathrm{~cm}^{-1}$ $(\mathrm{M}=\mathrm{Ir}$ ), which can be assigned to coordinated out-of-plane (and therefore non conjugated) carboxylato groups. The basic starting materials also react with $\mathbf{H}_{2} \mathrm{tDcp}$ to yield the dinuclear complexes Ia and Ib. All these reactions are summarized in Scheme 1.

The implications of the difference in behaviour between the two isomeric ligands are that when one of the carboxylato groups of the $\mathrm{cDcp}^{2-}$ anion has formed a chelate with the $\mathrm{N}$ of the pyrazine, the other is forced to rotate out of the plane of the aromatic ring to avoid the steric hindrance. It should be noted that the structure of the acid form of the ligand shows a dihedral angle of $34^{\circ}$ between the pyrazine ring and the plane defined by one of the carboxylic groups [16]. The potential chelate fragment formed by the pyrazine ring and the rotated carboxylato group is a much weaker ligand than the corresponding in-plane chelate. This poor coordinating ability of the former can be inferred from the second reaction in Scheme 1, in which no substitution of the labile chloro ligands of the anions $\left[\mathrm{MCl}_{2}(\mathrm{cDcp})\right]^{-}$takes place. Similar behaviour has been observed in the case of $\mathrm{Zn}(\mathrm{cDcp}) \cdot 3 \mathrm{H}_{2} \mathrm{O}$, [5] although there the polymeric structure allows coordination to the metal of both oxygens of the twisted carboxylato group. 


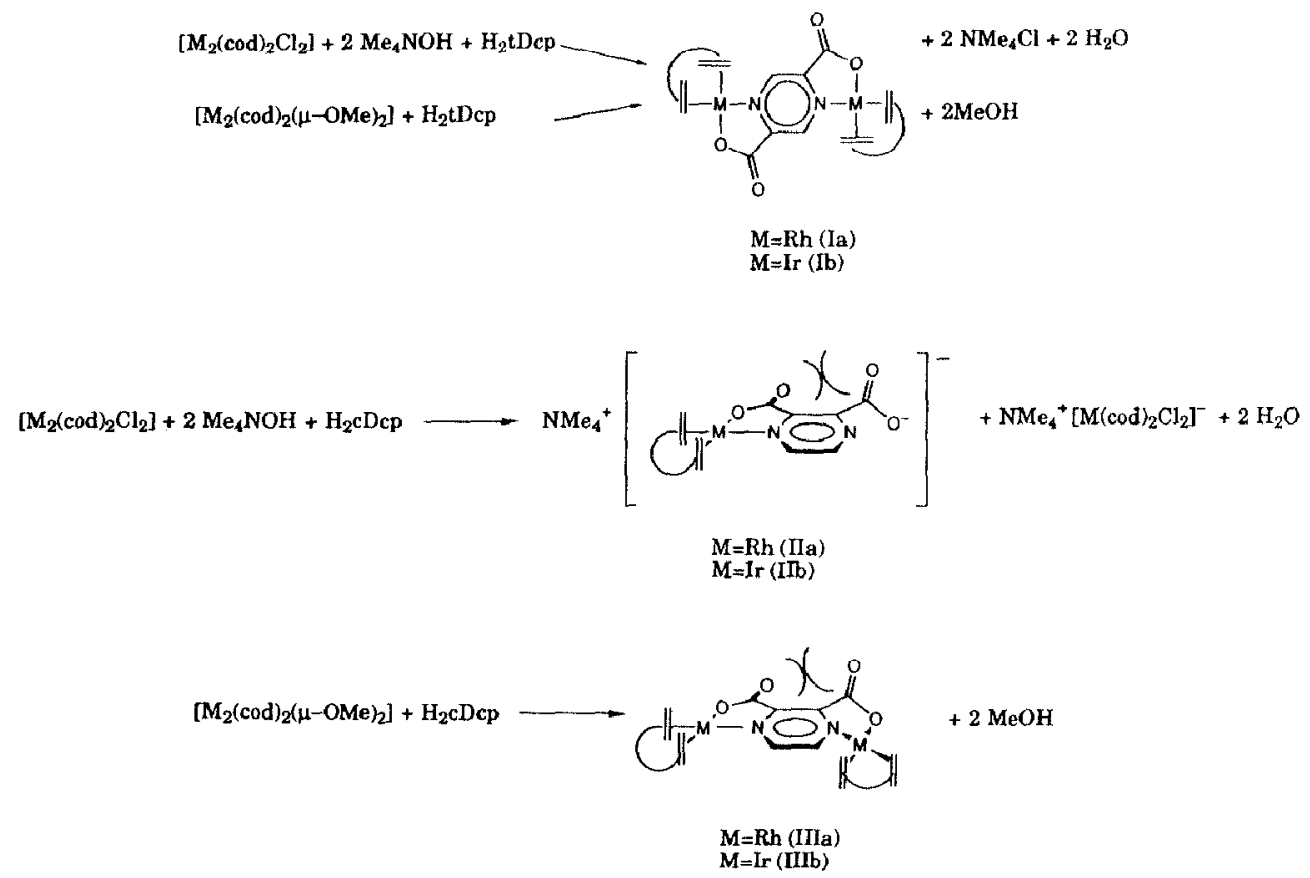

Scheme 1. Preparation of compounds I $\sim$ III.

When $[\mathrm{M}(\mu-\mathrm{OMe})(\mathrm{cod})]_{2}$ is used as starting material the very poorly coordinating $\mathrm{MeOH}$ is formed as side product rather than $\mathrm{Cl}^{-}$. In this case, the out-of-plane chelate is able to replace the alcohol molecules of the solvato complex to form the dinuclear species IIIa and IIIb. It is significant that the infrared spectra of the latter complexes are consistent with the presence of both a chelate in-plane and a twisted chelate ligand, which contrasts with the structure of the complex $\mathrm{Co}(\mathrm{cDcp}) \cdot 2 \mathrm{H}_{2} \mathrm{O}$, in which both carboxylato groups are rotated out of the plane of the pyrazine [4]. ${ }^{1} \mathrm{H}$ NMR spectra of the dinuclear rhodium and iridium complexes of $\mathrm{cDcp}^{2-}$ show a broad signal for the two heterocyclic protons, indicating a dynamic equilibrium between the in-plane and out-of-plane chelates. On the other hand, the dinuclear complexes of $\mathrm{tDcp}^{2-}$ show a single absorption for these protons, consistent with a symmetrical structure.

Steric interaction between the carboxylato groups at the 2 and 3 positions of the pyrazine six member ring has not been observed for any of the complexes of the ligands imidazole-4,5-dicarboxylic acid [11] and triazole-4,5-dicarboxylic acid [17]. The obvious conclusion is that the slight increment (ca. $12^{\circ}$ ) in the opening of the angle formed by the bonds between the heterocycle atoms and the carboxylate carbons is sufficient to preclude such distortion in the five member heterocycles.

When carbon monoxide was bubbled through solutions of the compounds Ia, Ib, IIIa, and IIIC the impure carbonyl derivatives were obtained in very low yield as insoluble dark materials. Because of the intractability of these solids, no further characterization was attempted. However, in the presence of a phosphine or phosphite ligand, the reaction with $\mathrm{CO}$ yields quantitatively the compounds $\left[\mathrm{M}_{2}(\mathrm{tDcp})(\mathrm{CO})_{2}\left(\mathrm{PR}_{3}\right)_{2}\right]$ and $\left[\mathrm{M}_{2}(\mathrm{cDcp})(\mathrm{CO})_{2}\left(\mathrm{PR}_{3}\right)_{2}\right](\mathrm{M}=\mathrm{Rh}, \mathrm{Ir} ; \mathrm{R}=\mathrm{Ph}, \mathrm{OPh}$, OMe). A single $\mathrm{CO}$ absorption was observed in the infrared spectra of these 
compounds, which is consistent with a $\mathrm{CO}$ trans-O-structure, related to that found for the mononuclear $\left[\mathrm{Rh}(\mathrm{pic})(\mathrm{CO})\left(\mathrm{PPh}_{3}\right)\right]$ (pic = 2-carboxypyridine) [18].

\section{Conclusions}

The ligands cDcp ${ }^{2-}$ and $\mathrm{tDcp}^{2-}$ differ markedly in their dinucleating properties. With the former the coordination ability of the second chelate is drastically reduced when one chelate has been formed, as a result of the repulsive interaction between the two carboxylate groups, whereas the ligand $\mathrm{tDcp}^{2-}$ readily forms dinuclear species. Neither ligand gave characterizable dinuclear tetracarbonyl species similar to those reported for dinucleating five member ring dicarboxyazolates. The lower basicity of the pyrazine ligands may be responsible for this difference.

\section{Acknowledgements}

J.C.B. thanks CAICYT(PB85-008) for financial support. P.G.R. acknowledges support from the donors of the P.R.F. administered by the American Chemical Society. J.C.B., and P.G.R. acknowledges support from the USA-Spain Joint Committee.

\section{References}

1 C.J. O'Connor, E. Sinn, Inorg. Chem., 20 (1981) 545; F. Cariati, L. Naldini, A. Panzanelli, F. Demartin; M. Manassero, Inorg. Chim. Acta, 69 (1983) 117.

2 R.L. Chapman, F.S. Stephens, R.S. Vagg, Inorg. Chim. Acta, 26 (1977) 247.

3 S.B. Brown, M.J.S. Dewar, Inorg. Chim. Acta, 34 (1979) 221.

4 P.P. Richard, D.T. Qui, E.F. Bertaut, Acta Cryst., B, 29 (1973) 1111.

5 P.P. Richard, D.T. Qui, E.F. Bertaut, Acta Cryst., B, 30 (1974) 628.

6 R.L. Dutta, S. Ghosh, J. Ind. Chem. Soc., 44 (1967) 290.

7 R.W. Matthews, R.A. Walton, Inorg. Chem., 10 (1971) 1433.

8 D. Sedney, A. Ludi, Inorg. Chim. Acta, 47 (1981) 153.

9 A.S. Bereblyum, V.A. Grinberg, M.L. Khidekel, V.V. Tsodikov, Izv. Akad. Nauk SSSR, Ser. Khim., (1973) 696.

10 M. Postel, F. Casabianca, Y. Gauffreteau, J. Fischer, Inorg. Chim. Acta, 113 (1986) 176.

11 J.C. Bayón, G. Net, P.G. Rasmussen, J.B. Kolowich, J. Chem. Soc., Dalton Trans., (1987) 3003; G. Net, J.C. Bayón, W.M. Butler, P.G. Rasmussen, J. Chem. Soc., Chcm. Commun., (1989) 1022.

12 J.C. Bayón, G. Net, P. Esteban, P.G. Rasmussen, D.F. Bergstrom, submitted.

13 (a) G. Giordano, R.H. Crabtree, Inorg. Synth., 19 (1979) 218; (b) G. Winkhau, H. Singer, Chem. Ber., 99 (1966) 3610.

14 R. Usón, L.A. Oro, J.A. Cabeza, Inorg. Synth. 23 (1985) 126.

15 C. Stoehr, J. Prakt. Chem., 55 (1897) 249.

16 F. Tukusagawa, A. Shimada, Chem. Lett., (1973) 1121.

17 J.C. Bayón, G. Net, P. Esteban, P.G. Rasmussen, to be published.

18 J.G. Leipoldt, G.J. Lamprecht, D.E. Graham, Inorg. Chim. Acta, 101 (1985) 123. 